\title{
Erratum to: Anaemia, Zinc and Copper Deficiencies Among Pregnant Women in Central Sudan
}

\author{
Mohamed Bushra • Elhassan M. Elhassan • Naji I. Ali • \\ Elfatih Osman • Khalid H. Bakheit • Ishag I. Adam
}

Published online: 19 August 2010

(C) Springer Science+Business Media, LLC 2010

\section{Erratum to: Biol Trace Elem Res \\ DOI 10.1007/s12011-009-8586-4}

The original version of this article unfortunately contained mistakes.

In table 1, it should be, Serum copper was not significantly lower in the anaemic subjects that in the non-anaemic subjects, $\mathrm{P}=0.7$, instead of $\mathrm{P}=0.02$. Thus in the abstract and results, it should be Serum copper was not significantly lower in the anaemic subjects that in the non-anaemic subjects, $\mathrm{P}=0.7$.

In the same table SD for haemoglobin of the non-anaemic subjects should be 1.6 instead of 16.2 .

All over the paper, the unit for serum zinc and copper should be $\mu \mathrm{g} / \mathrm{dL}$ instead of $\mu \mathrm{g} / \mathrm{ml}$.

The online version of the original article can be found at http://dx.doi.org/10.1007/s12011-009-8586-4.

M. Bushra $\cdot$ K. H. Bakheit • I. I. Adam $(\bowtie)$

Department of Obstetrics \& Gynecology, Faculty of Medicine, University of Khartoum, P. O. Box 102

Khartoum, Sudan

e-mail: ishagadam@hotmail.com

E. M. Elhassan

University of Geizera, Wad Medani, Sudan

N. I. Ali • E. Osman

Sudan Atomic Energy Commission, Khartoum, Sudan 